\title{
Temnocephala lutzi Monticelli (Platyhelminthes, Temnocephalida) ectosymbiont on two species of Trichodactylus Latreille (Crustacea, Decapoda, Trichodactylidae) from southern Brazil ${ }^{1}$
}

\author{
José F. R. Amato ${ }^{2}$, Suzana B. Amato ${ }^{2} \&$ Samantha A. Seixas ${ }^{3}$ \\ ${ }^{1}$ Contribution number 460 of the Departamento de Zoologia, Universidade Federal do Rio Grande do Sul. \\ ${ }^{2}$ Departamento de Zoologia, Instituto de Biociências, Universidade Federal do Rio Grande do Sul. Caixa Postal 15014, \\ 91501-970 Porto Alegre, Rio Grande do Sul, Brasil. E-mail: jfamato@terra.com.br; sbamato@ufrgs.br \\ ${ }^{3}$ Bolsista IC/PIBIC - CNPq/UFRGS. E-mail: samantha_bio@yahoo.com.br
}

\begin{abstract}
Temnocephala lutzi Monticelli, 1913, ectosymbiont on brachyuran freshwater crabs of the genus Trichodactylus Latreille, 1828 is recorded for the first time in the State of Rio Grande do Sul, southern Brazil. Two hundred and seventy-nine crabs of two species were examined: 211 Trichodactylus panoplus (von Martens, 1869) and 68 Trichodactylus fluviatilis Latreille, 1828 of which 51 (24.17\%) and 28 (41.17\%) were positive for $T$. lutzi, respectively. Crabs of both species carried eggs fixed, exclusively, on the floor of the branchial chambers and/or on the lower side of the gills. Adult as well as young specimens were found inside and outside the branchial chambers. The temnocephalans were always devoid of body pigmentation, although they kept the red eye pigment undiluted in specimens fixed by formalin. The cirrus of $T$. Iutzi showed the typical shape for the species, while the dorsolateral, post tentacular 'excretory' syncytial plates, demonstrated by two special techniques (silver nitrate staining and SEM), appeared with an elliptical shape and a central nephridiopore.

KEY WORDS. Brachyura, ectocommensals, Neotropical region, Rio Grande do Sul, South America, taxonomy.

RESUMO. Temnocephala lutzi Monticelli (Platyhelminthes, Temnocephalida) ectosimbionte sobre duas espécies de Trichodactylus Latreille (Crustacea, Decapoda, Trichodactylidae) da região sul do Brasil. Temnocephala Iutzi Monticelli, 1913, ectosimbionte sobre caranguejos braquiúros de água doce do gênero Trichodactylus Latreille, 1828, é assinalada pela primeira vez no Estado do Rio Grande do Sul, região sul do Brasil. Duzentos e setenta e nove caranguejos foram examinados: 211 de Trichodactylus panoplus (von Martens, 1869) e 68 de Trichodactylus fluviatilis Latreille, 1828, dos quais $51(24,17 \%)$ e $28(41,17 \%)$ estavam positivos para $T$. lutzi, respectivamente. Caranguejos das duas espécies apresentaram posturas de $T$. lutzi com os ovos fixados, exclusivamente, no interior das câmaras branquiais, sobre o assoalho e/ou na face interna das brânquias. Espécimes juvenis e adultos foram encontrados dentro e fora das câmaras branquiais. Os temnocefalídeos sempre se apresentaram sem pigmento corporal, embora o pigmento vermelho dos olhos tenha sido preservado nos espécimes fixados em formalina. Os cirros em $T$. lutzi apresentaram-se com a forma típica da espécie, as placas sinciciais dorsolaterais, pós-tentaculares 'excretoras', demonstradas através de duas técnicas especiais (nitrato de prata e MEV), apresentaram a forma elíptica com o nefridióporo central.

PALAVRAS CHAVE. América do Sul, Brachyura, ectocomensais, região Neotropical, Rio Grande do Sul, taxonomia.
\end{abstract}

MonTiCelui (1913) described Temnocephala lutzi from a brachyuran freshwater crab identified as "Telphusa sp." and declared "Sao Paulo", State of São Paulo (São Paulo), Brazil as the type locality for the new species. BAER (1931: 41) listed the same occurrence of T. lutzi, and commented on the validity of the generic name 'Telphusa' which also has been discussed by Pretzmann (1982), while surveying the river crabs of the western Mediterranean area. MagalHÃEs (2003) revised the Brazilian freshwater crabs in
Pseudothelphusidae and Trichodactylidae.

Pereira \& Cuocolo (1941), redescribed the species T. lutzi for the first time since the precarious original description, based on specimens from Trichodactylus petropolitanus (Göldi, 1886) collected in creeks of Pinheiros, a suburb of São Paulo City and also in the City of Piracicaba, São Paulo. DAmborenea (1994) described specimens of T. lutzi found on yet another host, Sylviocarcinus pictus (Milne-Edwards, 1853), from Rio Negro, 
Lago do Prato, Amazonas State and Rio Amapá, Amapá State, northern Brazil. Damborenea \& Cannon (2001), in a review of the Neotropical species of Temnocephala Blanchard, 1849, studied T. lutzi, but did not draw the cirrus neither the dorsolateral, post-tentacular 'excretory' syncytial plates.

The present report records $T$. lutzi from two new hosts of the genus Trichodactylus Latreille, 1828, Trichodactylus panoplus (von Martens, 1869) and Trichodactylus fluviatilis Latreille, 1828, documenting for the first time, photographically and through illustrations, the: 1) areas of egg deposition on the hosts, shape and color of the eggs, and relative position of the egg filament; 2) morphology of the young; 3 ) cirrus structure as revealed by different techniques; and 4) paired dorsolateral, post-tentacular, 'excretory' syncytial plates also as revealed by two different techniques.

\section{MATERIAL AND METHODS}

Collections of hosts extended from 1998 to 2004. Two hundred seventy-nine crabs were collected with dip nets and/ or large sand sieves, and transported alive to the Laboratório de Helmintologia, Universidade Federal do Rio Grande do Sul (UFRGS). Alive temnocephalans were obtained from each host species collected from several locations: T. panoplus - canals located $5 \mathrm{~km}$ West of Interstate Road BR-290, locality of Arrozeira, Municipality of Eldorado do Sul, $\left(30^{\circ} 01^{\prime} 36^{\prime \prime} \mathrm{S}, 51^{\circ}\right.$ $\left.22^{\prime} 42^{\prime \prime} \mathrm{W}\right)$; Praia Florida ( $\left.30^{\circ} 15^{\prime} 54^{\prime \prime} \mathrm{S}, 51^{\circ} 32^{\prime} 25^{\prime \prime} \mathrm{W}\right)$, and Arroio do Conde $\left(30^{\circ} 05^{\prime} 73^{\prime \prime} \mathrm{S}, 51^{\circ} 31^{\prime} 63^{\prime \prime} \mathrm{W}\right)$, both in the Municipality of Guaíba, and Rio Jacuí, at Ilha da Pintada (3002'23"S, $\left.51^{\circ} 25^{\prime} 49^{\prime \prime} \mathrm{W}\right)$, Municipality of Porto Alegre. T. fluviatilis - Arroio Carvão (29³2'29"S, 50¹3'49”W), Arroio Água Parada $\left(29^{\circ} 66^{\prime} 20^{\prime \prime} \mathrm{S}, 050^{\circ} 21^{\prime} 15^{\prime \prime} \mathrm{W}\right)$, and Arroio Forqueta $\left(29^{\circ} 32^{\prime} 17^{\prime \prime} \mathrm{S}\right.$, $\left.50^{\circ} 14^{\prime} 44^{\prime \prime} \mathrm{W}\right)$, all in the Municipality of Maquiné; locality of Vale das Trutas, head waters of Rio das Antas $\left(28^{\circ} 47^{\prime} 00^{\prime \prime} \mathrm{S}\right.$, $49^{\circ} 50^{\prime} 53^{\prime \prime}$ ), Municipality of São José dos Ausentes. All municipalities in the State of Rio Grande do Sul.

Some specimens were fixed in cold A.F.A., under slight cover slip pressure, stained in Delafield's hematoxylin, cleared in cedar oil, and mounted in Canada balsam, for internal morphometry (Амато \& Амато 2005).

The morphology of the paired, dorsolateral, post-tentacular 'excretory' syncytial plates was studied in live specimens fixed with hot $\left(60^{\circ} \mathrm{C}\right)$ silver nitrate (SN) (RomeIs 1968, Joffe et al. 1995). For scanning electron microscopy (SEM), specimens were flooded with hot $\left(90^{\circ} \mathrm{C}\right) 10 \%$ buffered formalin $(\mathrm{HF})$, without cover slip pressure and washed several times with distilled water, dehydrated in a graded ethanol/acetone series, and critical point dried; coated with gold, and examined with a Jeol (JSM-6060) scanning electron microscope. Cirrus morphology was studied after micro dissection and mounting the cirri in de Faure (deF) medium (CANNON \& SEwELl 1995). Groups of unhatched eggs, removed by scrapping the floor of the branchial chamber were dehydrated, cleared in cedar oil, and mounted in Canada balsam. The description of the specimens follows the Delta System format (Dallwitz \& Paine 1986).

Photomicrographs were taken with a Zeiss Axiolab microscope equipped with phase contrast (or just the phase contrast condenser) or with a Leica DMR Hc differential interference contrast (DIC) microscope with Nomarski's prisms. Measurements are in micrometers $(\mu \mathrm{m})$ unless otherwise indicated; ranges are followed (between parentheses) by the mean, the number of specimens measured for a given character (when different than 16) and the standard deviation values. The terminology used to describe the male reproductive structures follows Cannon (1993), Cannon \& Sewell (1995), and Sewell \& CANNON (1998). Drawings were made with a drawing tube on a Leitz Dialux 20-EB microscope.

Voucher specimens fixed in HF and cold A.F.A., as well as slides containing individual cirri mounted in deF, and unhatched eggs, were deposited in the Coleção Helmintológica do Instituto Oswaldo Cruz (CHIOC), Rio de Janeiro, Rio de Janeiro, Brazil and in the Coleção de Invertebrados, Instituto Nacional de Pesquisas da Amazônia (INPA), Manaus, Amazonas, Brazil.

\section{RESULTS}

\section{Temnocephala Iutzi Monticelli, 1913}

Figs 2-24

Description (based on 477 specimens collected; 101 adult whole-mounted specimens killed in cold A.F.A., under slight cover slip pressure); 59 juveniles; two specimens mounted on stubs for SEM; 13 cirri mounted in deF; 4 mounted specimens (fixed with SN); 41 mounted specimens (fixed with HF); 16 specimens measured:

External characteristics. Body shape elliptical (Figs 6 and 16); length (without tentacles) 700-1090 (931, 109), 410-1015 $(605,166)$; elliptical, wider at mid-body; adhesive disk sub-ventral, pedunculate, $130-350(244,55)$ in diameter; eye spots round to irregular shaped, with red pigment in live specimens (Figs 7 and 9 arrows); pigment dissolving if specimens are fixed in ethanol, but not in formalin.

Epidermal mosaic (demonstrated through staining with SN and observed with SEM) with two dorsolateral, post tentacular, elliptical-shaped (Figs 9, 10, 16, and 17 head arrows), 'excretory' syncytial plates, extending from middle insertion of first and fifth tentacles, respectively; left plate 135-183 $(159, \mathrm{n}=2$, 34) long, 68-73 (71, $\mathrm{n}=2,3)$; right plate 130-174 $(152, \mathrm{n}=2,31)$ long, 59-73 $(66, \mathrm{n}=2,10)$; length of 'excretory' syncytial plates/ total body length, without tentacles, relationship of 4: 1 . Excretory pore (nephridiopore) well centered inside the area of each 'excretory' syncytial plate (Figs 9, 10, 16 and 17 n).

Alimentary system. Mouth surrounded by muscular sphincter (Figs 11 and 12), between first and second thirds of body; pharynx wider than long, 130-250 $(205, \mathrm{n}=10,40)$ long, 165-275 $(223, \mathrm{n}=10,42)$ wide, with a large sphincter (Fig. 12); intestine saccular, with conspicuous septations (Figs 11 and 12) in young and in adult specimens. 

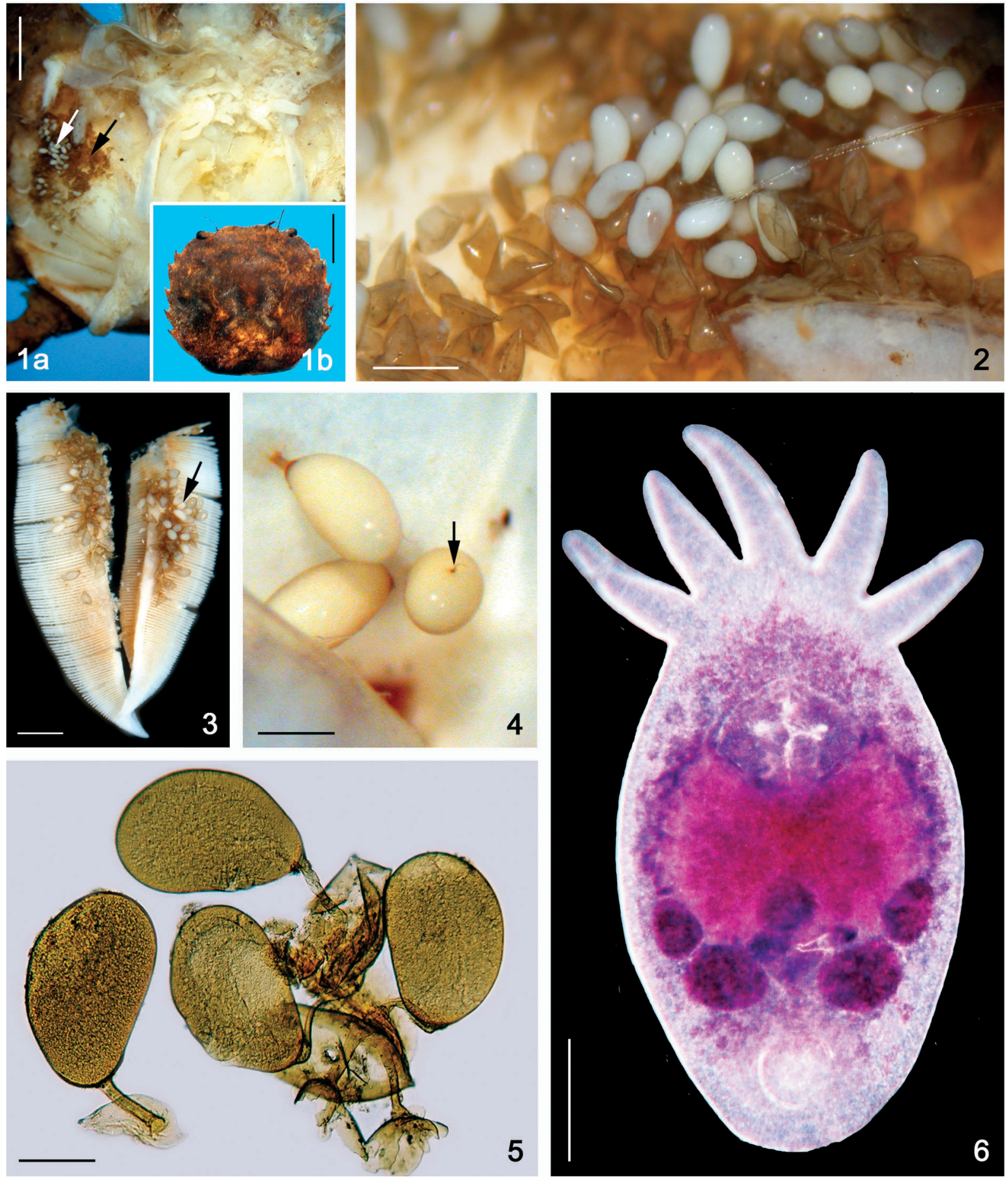

Figures 1-6. (1) Trichodactylus panoplus: (1a) specimen without the carapace, showing patches of eggs (arrows), hatched (dark areas, black arrow) and unhatched (white areas, white arrow), bar $=5 \mathrm{~mm}$; ( $1 \mathrm{~b}$ ) inset with the carapace removed (dorsal view), bar $=7 \mathrm{~mm}$; (2-6) Temnocephala lutzi: (2) eggs (hatched and unhatched) on the floor of the branchial chamber of $T$. panoplus, bar $=500 \mu \mathrm{m}$; (3) two anterior gills removed from the branchial chamber, showing hatched and unhatched eggs (arrow) on their inner surface, bar $=1 \mathrm{~mm}$; (4) higher magnification of eggs, showing filament (arrow), bar = $200 \mu \mathrm{m}$; (5) eggs cleared in cedar oil showing their shape, width and length of peduncles, $\mathrm{bar}=300 \mu \mathrm{m}$; (6) T. lutzi, adult specimen, seen with phase contrast condenser, bar $=100 \mu \mathrm{m}$.

Revista Brasileira de Zoologia 22 (4): 1085-1094, dezembro 2005 

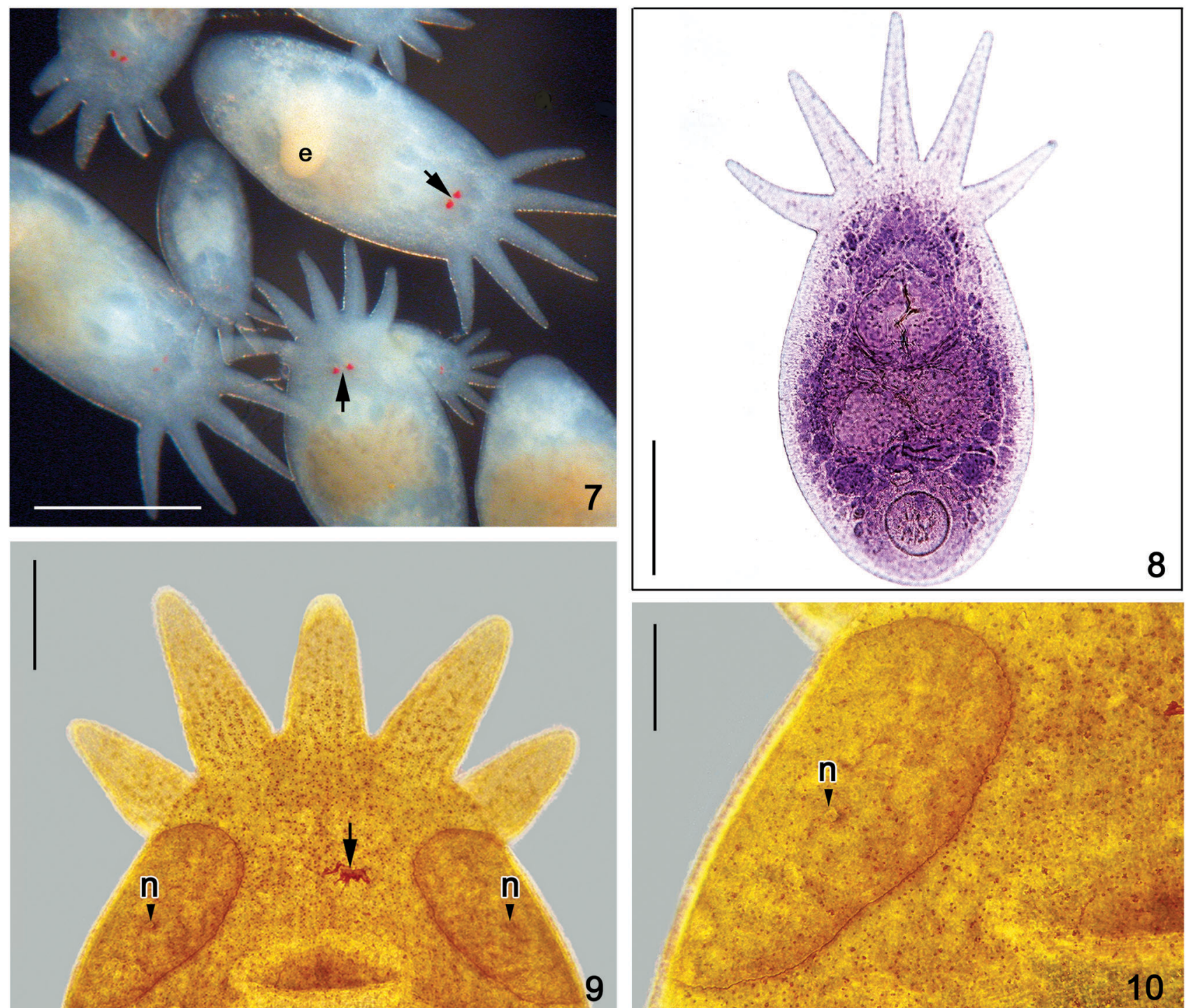

Figures 7-10. Temnocephala lutzi: (7) specimens showing their typical shape when fixed with hot formalin, the red eye pigmentation (arrows) and a developing egg (e), bar = 1 mm; (8) young specimen, bar = $200 \mu \mathrm{m}$; (9-10) specimen stained by silver nitrate (9) showing the elliptical dorsolateral 'excretory' syncytial plates and central nephridiopores ( $n$, head arrows) and the red eye pigment (arrow), bar $=100 \mu \mathrm{m} ;(10)$ higher magnification, $\mathrm{bar}=50 \mu \mathrm{m}$.

Excretory system. Excretory ampullae, round to elongate, at level of mouth (Fig. 12 ea), generally directed outwards with the nephridiopore in the center of the 'excretory' syncytial plates.

Glands. Rhabdite producing glands large, numerous, forming bunches, in lateral fields of the body; extending from mid-level of the intestinal sac to the adhesive disc, with inconspicuous ducts, best observed in very young specimens still without vitellaria (Fig. $11 \mathrm{rg}$ ). Two irregular shaped Haswell cells (Figs $12 \mathrm{hc}$ and 21 head arrows), showing little affinity with hematoxylin, in front of the eyespots and the brain transverse band; left cell in pair 35-100 $(53, \mathrm{n}=11,22)$ across, right cell 30-88 $(48, \mathrm{n}=10,18)$ across. Disc glands (Fig. 13) between adhesive disc and genital complex, forming bunches extending from mid-level of posterior testes to the anterior border of the adhesive disc including to two, large, more central cells (Figs 13 and 23 lgc arrows), 55-78 (63, $\mathrm{n}=8,8)$ long.

Reproductive system. Female. Gonopore between middle and posterior thirds of body; ovary pyriform, 35-100 (57, n = $14,18)$ long, $30-75(55, \mathrm{n}=14,12)$ wide (Figs $22-23 \mathrm{ov})$; seminal receptacles not observed; vitellaria covering the dorsal and the ventral sides of the intestinal sac, sometimes (in specimens killed with cover slip pressure) exceeding this limit (Figs 12

Revista Brasileira de Zoologia 22 (4): 1085-1094, dezembro 2005 

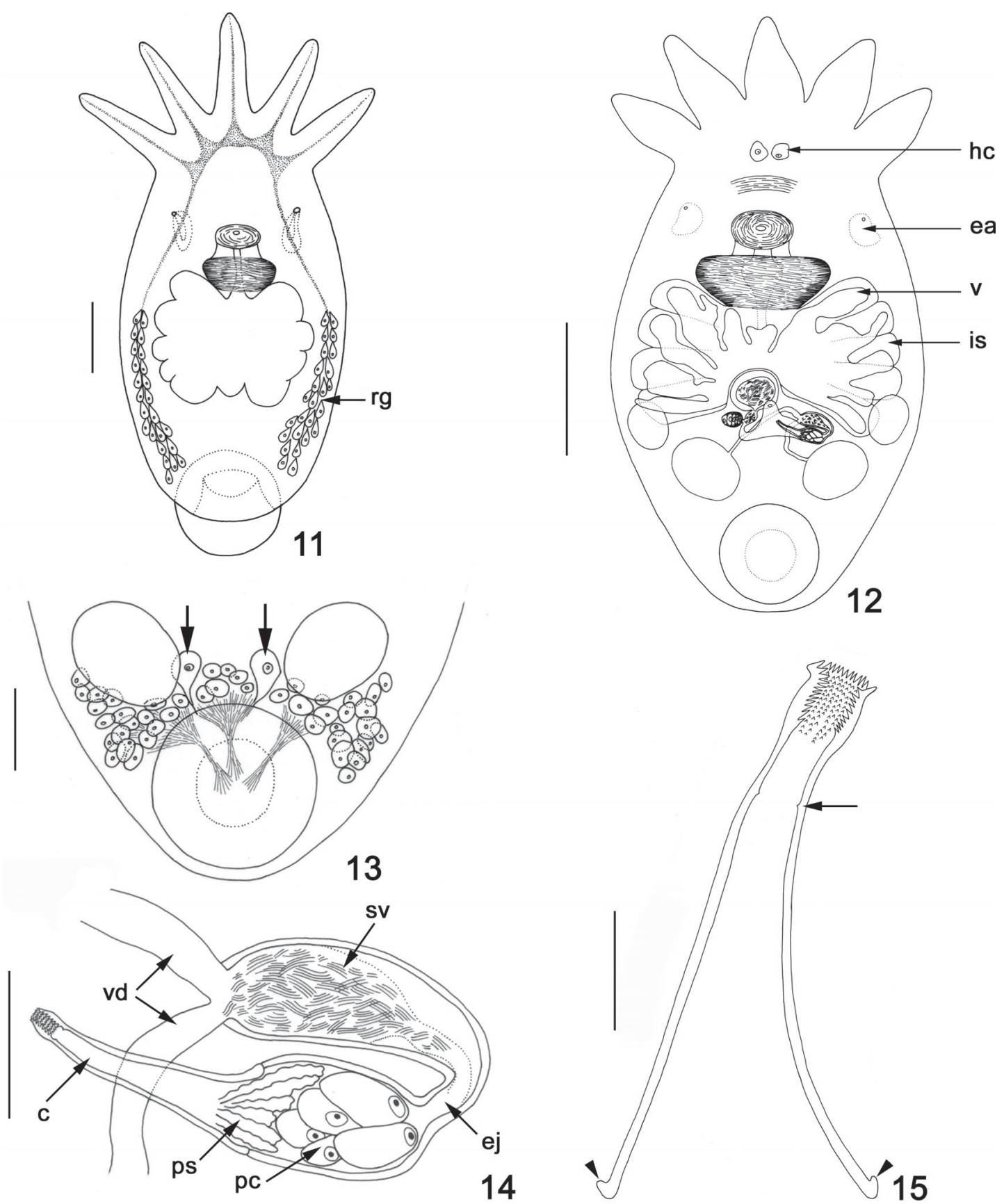

Figures 11-15. Temnocephala lutzi: (11) very young specimen showing the distribution of the rhabdite producing glands $(\mathrm{rg})$, bar $=100$ $\mu \mathrm{m}$; (12) partial diagram of an adult specimen, showing the intestinal sac (is), and the distribution of vitellaria (v), the Haswell cells (hc), and the excretory ampullae (ea), bar = $500 \mu \mathrm{m} ;(13)$ disc glands, showing the pair of larger glands (arrows), bar = $150 \mu \mathrm{m} ;(14)$ vasa deferentia (vd arrows), seminal vesicle (sv), ejaculatory duct (ej), prostatic cells (pc), prostatic secretion (ps), and cirrus (c), bar = $50 \mu \mathrm{m}$; (15) cirrus, showing the proximal limit of the introvert (arrow) and the shafts proximal end thicker rim (head arrows), bar $=20 \mu \mathrm{m}$.

and $22 \mathrm{v}$ ); genital atrium spacious, elongate (Fig. 22 ga), vagina short, incospicuous, without observable muscular sphincter (Fig. $22 \mathrm{va}$ ), opening in front of the cirrus' introvert; ve- sicula resorbens (Figs 22-23 vr), thick walled, 40-113 $(72, \mathrm{n}=$ $14,25)$ long, 50-138 $(88, \mathrm{n}=14,26)$ wide, indenting intestinal sac and vitellaria, posteriorly. Eggs with peduncles of medium 

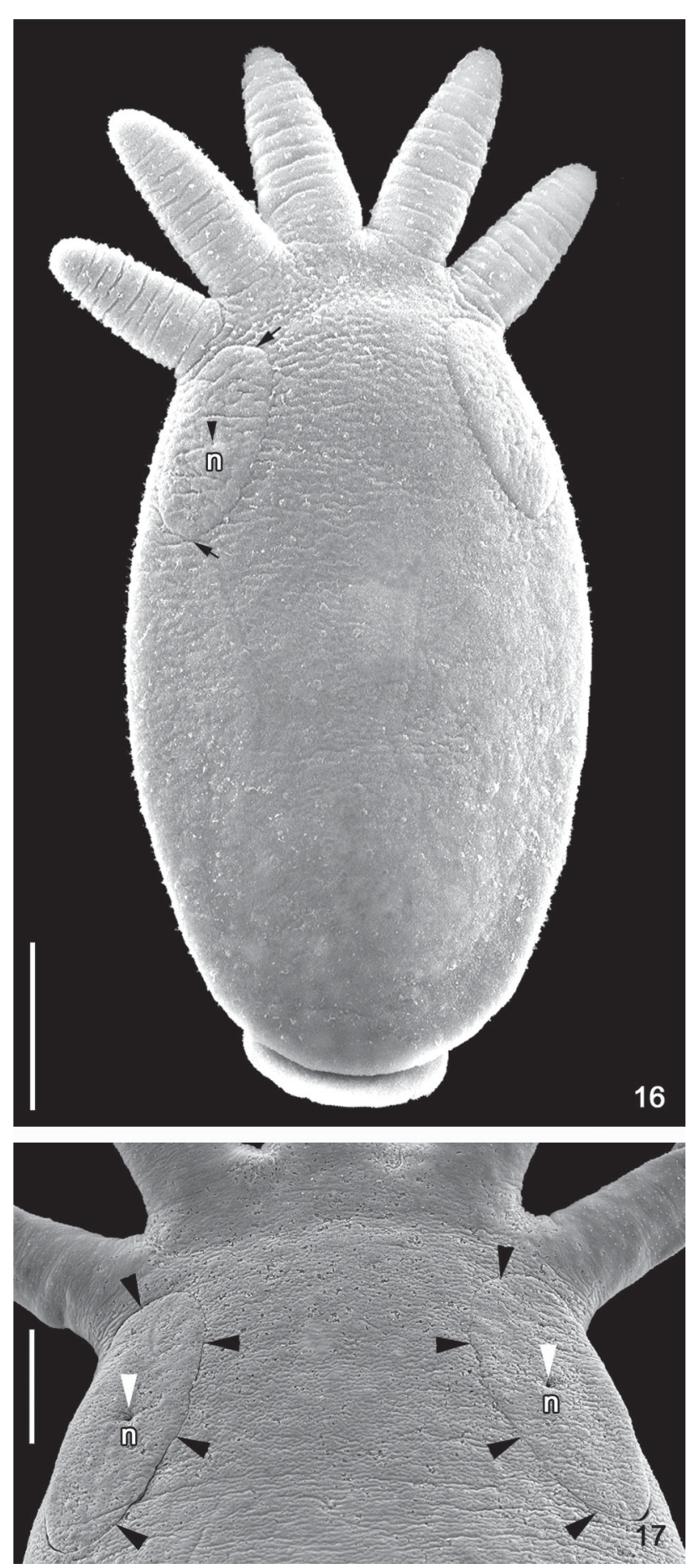

Figures 16-17. Temnocephala lutzi, seen with SEM: (16) entire specimen showing the anterior and posterior limits, and the relationship between the total body length and the length of the elliptical dorsolateral 'excretory' syncytial plates, bar $=125 \mu \mathrm{m}$; (17) higher magnification to show the syncytial plates (head arrows) and the centralized nephridiopores (head arrow $-\mathrm{n}$ ), bar $=50 \mu \mathrm{m}$. length (Fig. 5), always deposited inside the branchial chambers, on the floor (Fig. 1a unhatched eggs white arrow and hatched eggs black arrow) and on the inner side of the anterior gills (Fig. 3 arrow), 260-490 (343, n = 7, 96) long, 170-270 (201, $\mathrm{n}=7,44)$ wide, peduncles $30-90(60, \mathrm{n}=7,22)$ long; and a filament displaced to the side (Fig. 4 arrow).

Male. Testes four, anterior and posterior testes of different sizes, oblique; anterior testes round to oval, sometimes more elongate and slightly lobed; posterior testes always more voluminous; right anterior testis round to oval, 75-263 $(134,46)$ long; 45-128 $(87,25)$ wide; right posterior testis round, 115-263 (167, 44) long, 55-225 $(128,48)$ wide; left anterior testis oval, 70-243 $(137,47)$ long, 48-198 $(93,36)$ wide; left posterior testis round to oval, $117-390(176,67)$ long, $68-233(133,45)$ wide; both vasa deferentia wide (Figs 22 and $24 \mathrm{vd}$ ) uniting in large, pyriform, thick-walled, seminal vesicle (Figs 22 and $24 \mathrm{sv}$ ), 60-123 $(88,16)$ long, 25-50 $(38, \mathrm{n}=9,10)$ wide; prostatic bulb (Figs 22 and $23 \mathrm{pb}) 40-73(55, \mathrm{n}=10,10)$ long, 35-55 $(44, \mathrm{n}=10,6)$ wide, cirrus short (Figs 14, 18 and $24 \mathrm{c}$ ), slightly bent anteriorly (30\% from distal end), 87-109 $(96, \mathrm{n}=10,8)$ long, shaft 55-82 $(68, \mathrm{n}=10 ; 8)$ long; $30-46(37, \mathrm{n}=10 ; 4)$ wide at base; maximum introvert width at level of swelling, 9-16 $(10, \mathrm{n}=10,2)$, introvert's swelling portion 21-36 $(26, \mathrm{n}=10 ; 5)$ long, observed in two different focusing planes with the Nomarski's (DIC) microscopy (Figs 19 and 20). Proximal limit of introvert marked with a narrowing of the lumen's diameter, and is seen from the side as two fine spikes (Fig. 15 arrow). Base of cirrus shaft with thick borders in adult specimens (as growth of cirrus starts from distal extremity) showing growth is complete (Fig. 15 head arrows). Ratio between total length of cirrus and maximum width of shaft's base 2.54:1; ratio between total length of cirrus and total length of introvert 3.69:1. Introvert spines displaced, in approximately, 16-20 longitudinal rows of 12-15 spines each (Figs 19 and 20); some longitudinal rows with more spines than others.

Type host and locality. "Telphusa sp. ( = Potamon sp.), Sao Paulo", Brazil (Monticelli 1913), as cited by Damborenea \& CanNON (2001), but it is probably Trichodactylus petropolitanus Göldi, 1886, São Paulo, State of São Paulo.

Other hosts and localities. Trichodactylus panoplus (von Martens, 1869) (new host record) and Trichodactylus fluviatilis Latreille, 1828 (new host record); Trichodactylus petropolitanus Göldi, 1886, suburb of Pinheiros, São Paulo City and City of Piracicaba, SP, Brazil (PereIra \& Cuocolo 1941); Sylviocarcinus pictus (Milne-Edwards, 1853), Rio Negro, Lago do Prato, Amazonas State and Rio Amapá, State of Amapá, Brazil (DAmborenea 1994).

Other localities (present work). T. panoplus - canals on the road to the locality of Arrozeira, Municipality of Eldorado do Sul ( $2 \mathrm{~km}$ to the North of Interstate Road BR-290 (30 01'36"S, $\left.051^{\circ} 22^{\prime} 42^{\prime \prime} \mathrm{W}\right)$; Praia Florida $\left(30^{\circ} 15^{\prime} 54^{\prime \prime} \mathrm{S}, 051^{\circ} 32^{\prime} 25^{\prime \prime} \mathrm{W}\right)$ and Arroio do Conde, Municipality of Guaíba $\left(30^{\circ} 05^{\prime} 73^{\prime \prime}\right.$, $\left.051^{\circ} 31^{\prime} 63^{\prime \prime W}\right)$; Rio Jacuí, at Ilha da Pintada $\left(30^{\circ} 02^{\prime} 23^{\prime \prime}\right.$, $\left.051^{\circ} 25^{\prime} 49^{\prime \prime} \mathrm{W}\right)$, Municipality of Porto Alegre. T. fluviatilis Arroio Carvão (29³2'29”S, 050¹3’49”W), Arroio Água Parada

Revista Brasileira de Zoologia 22 (4): 1085-1094, dezembro 2005 

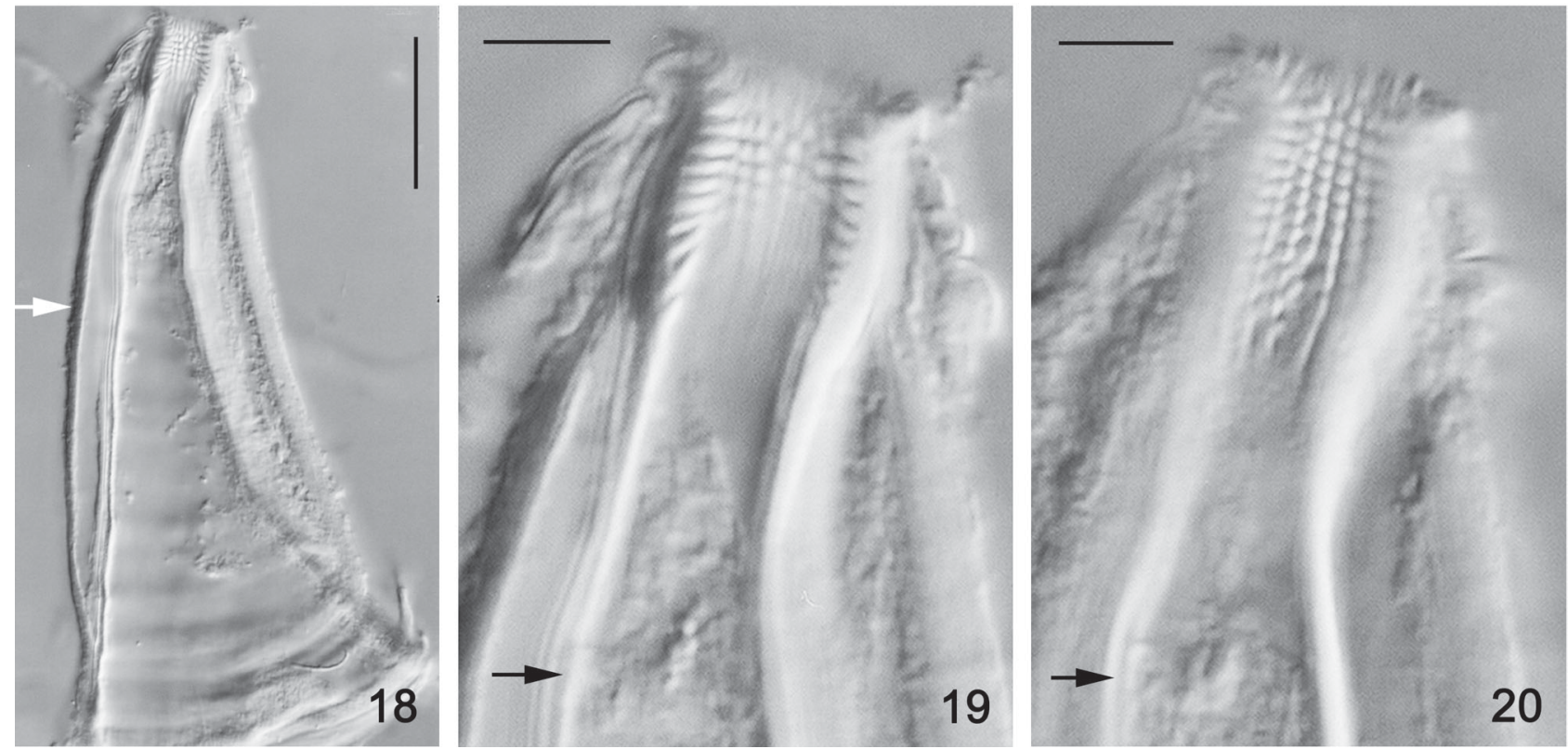

Figures 18-20. Temnocephala lutzi, photomicrographs of a cirrus, seen with Nomarski's DIC microscopy: (18) entire cirrus, showing the bent distal region and the 'sleeve-like' sheath (white arrow), bar $=25 \mu \mathrm{m}$; (19) cirrus introvert showing how spines are inserted laterally (lateral focus), bar $=5 \mu \mathrm{m}$; (20) cirrus introvert showing the number of spines along a longitudinal row with focus on the lower wall, bar $=5 \mu \mathrm{m}$. Black arrows show point of bending.

$\left(29^{\circ} 66^{\prime} 20^{\prime \prime} \mathrm{S}, 050^{\circ} 21^{\prime} 15^{\prime \prime} \mathrm{W}\right)$, and Arroio Forqueta (29³2'17"S, $\left.050^{\circ} 14^{\prime} 44^{\prime \prime} \mathrm{W}\right)$, Municipality of Maquiné; Vale das Trutas, head waters of Rio das Antas (28 $47^{\prime} 00^{\prime \prime}$ S, 049 $50^{\prime} 53^{\prime \prime}$ W), Municipality of São José dos Ausentes, all in the State of Rio Grande do Sul, Brazil.

Site. Branchial chambers and external surface of body; eggs always located inside the branchial chamber, on the floor and over the lower side of gills, in both T. panoplus and $T$. fluviatilis.

Prevalences. $41.17 \%$ in T. fluviatilis and $24.17 \%$ in $T$. panoplus.

Helminth deposited specimens. CHIOC $\mathrm{N}^{\circ} \mathrm{s} 36.601$, 36.602 a-b - vouchers specimens ex T. panoplus; CHIOC $\mathrm{N}^{\mathrm{o}} \mathrm{s}$ 36.606 - cirrus in deF ex T. panoplus; CHIOC Nos 36.603, 36.604, 36.605 - voucher specimens ex T. fluviatilis; CHIOC Nos 36.607 - cirrus in deF ex T. fluviatilis. INPA Noo 392, 393, 394 - voucher specimens ex T. fluviatilis; INPA Nos 389, 390, 391 - vouchers specimens ex T. panoplus; INPA N ${ }^{\circ}$ S 395, 396 - cirrus in deF ex T. panoplus.

Host specimens deposited. CCDZ - UFRGS - T. panoplus: Rio Jacuí, at Ilha da Pintada $\mathrm{N}^{\circ}$ s 3975-3979; Praia Florida $\mathrm{N}^{\circ} \mathrm{s}$ 3985-3987; Arroio do Conde $N^{\circ}$ s 3992-3993; Arrozeira $N^{\circ} s 3994$ 3995. T. fluviatilis: Arroio Carvão (middle strech) $\mathrm{N}^{\circ} \mathrm{s} 3863-3867$; Arroio Carvão (lower strech) $\mathrm{N}^{\mathrm{o}} \mathrm{s} 3868-3872$; Arroio Carvão $\mathrm{N}^{\mathrm{o}} \mathrm{s}$ 3887-3892; Vale das Trutas, head waters of Rio das Antas $\mathrm{N}^{\mathrm{o}} \mathrm{s}$ 3965-3966; Arroio Água Parada Nos 3967-3974; Arroio Forqueta $\mathrm{N}^{\mathrm{o}} \mathrm{s} 38-73-3875$.
Other specimens examined. Temnocephala lutzi Monticelli, 1913 - INPA n ${ }^{\circ}$ 416a-d (Brazil, AM, Rio Negro, Arquipélago de Anavilhanas, Lago do Prato. ex Sylviocarcinus pictus - Decapoda: Trichodactylidae, Célio Magalhães leg.) of DAmborenea (1994). Temnocephala lutzi Monticelli, 1913 - INPA n 417 (Brazil, AP, Rio Amapá Grande. ex Sylviocarcinus pictus - Decapoda: Trichodactylidae, Célio Magalhães leg.) of DAmBoreneA (1994).

Remarks. A number of considerations have been made along the time, because Monticelli (1913) described T. lutzi from a crab host that he called "Telphusa sp." and declared "Sao Paulo", State of São Paulo (SP), Brazil as the type locality for the new species. BAER (1931: 41) listing the same material of $T$. lutzi used by Monticelli to describe the new species, referred: "Habitat: Cavité branquiale de Telphusa sp. Localité: Sao Paolo", and the following comment in a footnote: "D'après les renseignements qui nous ont été obligeamment communiqués par le Dr. J. Roux de Bále, le genre Telphusa = Potamon . Mais ce genre n' existe pas en Amérique du Sud. Il s'agit done d'un Crustacé mal determine". The validity of the generic name Thelphusa also has been discussed by PretzMann (1982), while surveying the river crabs of the western Mediterranean area. Dr Célio Magalhães stated in a letter to us: "As to the question of Telphusa or Thelphusa, what I know is that Telphusa is a valid generic name of Insecta: Lepidoptera: Gelechiidae, whose author is Chambers, 1872. Thelphusa has been proposed by Latreille, 1819 for a freshwater crab, but Ortmann (1896) verified that it was synonym of Potamon, proposed by Savigny, 1816 . 


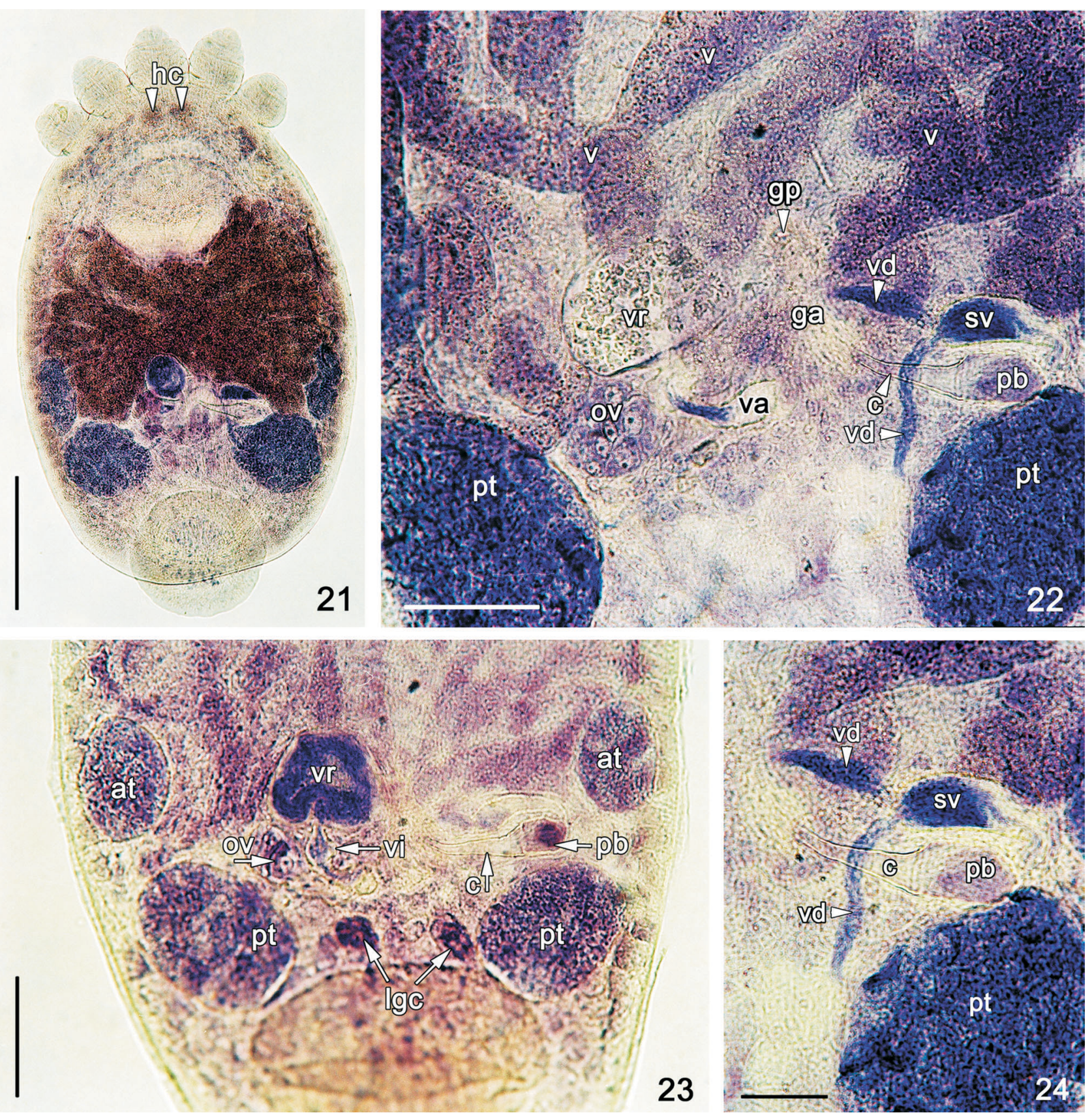

Figures 21-24. Temnocephala lutzi, selected characters in the internal anatomy: (21) entire specimen, fixed with cold A.F.A. and slight compression (Haswell cells hc, head arrows), bar $=250 \mu \mathrm{m}$; (22) adult specimen, male and female reproductive apparatuses, bar $=100 \mu \mathrm{m} ;(23)$ old specimen, reproductive system, including the two large disc gland cells, bar $=100 \mu \mathrm{m} ;(24)$ male reproductive system, bar $=50 \mu \mathrm{m}$. Legend for figures 22-24: anterior testes (at), cirrus (c), genital atrium (ga), genital pore (gp), large glandular disc cells (lgc), ovary (ov), prostatic bulb $(\mathrm{pb})$, posterior testes (pt), seminal vesicle (sv), vagina (va), vas deferens (vd), vitellaria (v), 'vesicula intermedia' (vi), vesicula resorbens (vr).

But I believe that Thelphusa is not used for any genus or supra generic taxon within the Brachyura. It has been, by tradition associated to a freshwater crab and many valid taxa (generic and supra generic) were named using combinations of this word". Thus, the type host of $T$. lutzi should be a species of Trichodactylus, occurring in SP.

Revista Brasileira de Zoologia 22 (4): 1085-1094, dezembro 2005 
Temnocephala lutzi is one of the four species of temnocephalans epizoic over trichodactylids recorded in Brazil, and one of the six recorded in the world. Although this species has been described by Monticelli (1913) and re-described by Pereira \& Cuocolo (1941), this is the first time that it is studied by SN and SEM techniques, which require live specimens to be killed/fixed by different fixatives. These techniques have shown that $T$. lutzi has elliptical syncytial plates (Figs 9 and 17), with the excretory pores at the center (Fig. $10 \mathrm{n}$ ). Another aspect that is necessary to document is the shape of the unhatched eggs, to show the relative position of the filament, which, in the case of $T$. lutzi is not located at the anti-peduncular extremity (Fig. 4 arrow).

Damborenea \& CANNON (2001) re-examined 19 Neotropical species of the genus Temnocephala, showing the epidermic 'excretory' sincicial plates, with differences in the shapes and position of the excretory pore inside the plates. The epidermic, post-tentacular 'excretory' syncytial plates of T. lutzi are shown for the first time to have an elongated elliptical shape which differs from the plates of the seven species illustrated by Damborenea \& CANNON (2001), from those of T. cyanoglandula Amato, Amato \& Daudt, 2003, and T. curvicirri Amato \& Amato, 2005, demonstrated using the SN and MEV techniques in species from the State of Rio Grande do Sul (Амато et al. 2003, Амато \& Амато 2005). Because T. lutzi has been found to cooccur in T. fluviatilis with another species which is being described and illustrated in a separate paper, at first, the separation of the specimens in mixed infestations posed a problem. But, providentially, the shape of the epidermic, post-tentacular 'excretory' syncytial plates found in T. lutzi are well distinct than those of the co-occurring species.

Previous authors have not considered the distribution and position of the rhabdite producing glands to be of much systematic value. The size, distribution, and position of these glands seen in T. lutzi have never been illustrated. They differ from those of other species described previously, the distribution of these glands in T. lutzi range from the mid-line of the intestinal sac to the anterior border of the adhesive disc superimposed to the disc glands.

The absence of seminal receptacles promoted a discussion over a peculiar structure found in the female reproductive system, which is an expansion of the duct that connects the vesicula resorbens to the ootype and the vagina (Fig. $23 \mathrm{vi}$ ). Damborenea (1994), describing T. kingsleyae, illustrated a similar structure to this reported in $T$. lutzi (present paper), a structure called "vesicula intermedia" would have the same function of seminal receptacles, explaining the absence of the later.

Damborenea (1994) found specimens of T. lutzi with smaller measurements than those found by Pereira \& Cuocolo (1941). Now we have specimens with measurements still smaller than those given by DAMBORENEA (1994). We consider the smaller measurements of our specimens a case of intraspecific variation.

Pereira \& Cuocolo (1941) described the cirrus as "short and bent in an angle near the distal portion, showing thus two parts, one long and straight and the other short and vertical. At the distal extremity it has a crown of small, very delicate, and chitin spines". This description has been confirmed by DAmborenea (1994).

In the present paper, micro dissection of the cirrus mounted in deF medium made possible the observation of the real complexity of the inflated portion of the introvert, as well as to obtain DIC photomicrographs and measurements of the cirri laying flat, to count the number of spines in each longitudinal row, the approximate number of longitudinal rows, and the position of the inner projections which limit the proximal limit of the introvert.

\section{ACKNOWLEDGEMENTS}

The authors are indebted to: Dr Célio Magalhães, Curator, Coleção de Invertebrados, Instituto de Pesquisas da Amazônia, Manaus, AM, for kindly loaning specimens of T. lutzi ex. S. pictus, from northern Brazil, for accepting voucher specimens of T. lutzi to be deposited in the Coleção de Invertebrados do INPA, and for his very helpful nomenclatorial comments on the genus Thelphusa; Prof. MSc. Fábio Vilella for the collection of many specimens of $T$. fluviatilis and valuable field information about the crab habitats in the creeks of the Rio Maquiné watershed where the specimens of T. fluviatilis were collected; Dr. Georgina Bond-Buckup, Departamento de Zoologia, UFRGS, for the discussion of crab anatomy; Drs Jorge Ernesto de Araújo Mariath, Rinaldo Pires dos Santos, and their research associates in the Laboratório de Anatomia Vegetal, Instituto de Biociências, UFRGS, for granting us permission to use the Leica DMR Hc Differential Interference Contrast (DIC) microscope; Miriam S. dos Santos Vianna and Moema Q. Vieira, Centro de Microscopia Eletrônica, UFRGS for SEM sample preparation and operation; José Renato da Roza Seixas and Maristela T. Alves Seixas for their help in the field work; Luiz Carlos Campos Daudt and Cassandra de Moraes Monteiro for their help in the laboratory.

\section{REFERENCES}

Amato, J.F.R.; S.B. Амato \& L.C.C. Daudt. 2003. New species of Temnocephala Blanchard (Platyhelminthes, Temnocephalida) ectosymbiont on Aegla serrana Buckup \& Rossi (Crustacea, Anomura) from southern Brazil. Revista Brasileira de Zoologia, Curitiba, 20 (3): 493-500.

Aмato, J.F.R. \& S.B. Амато. 2005. New species of Temnocephala Blanchard (Platyhelminthes, Temnocephalida) ectosymbiont on giant water bugs, Belostoma spp (Hemiptera, Belostomatidae) from southern Brazil. Revista Brasileira de Zoologia, Curitiba, 22 (1): 107-118.

BAER, J.-G. 1931. Étude monographique du groupe des Temnocephales. Bulletin Biologique de la France et de la Belgique, Paris, 1: 1-57.

Cannon, L.R.G. 1993. New temnocephalans (Platyhelminthes): ectosymbionts of freshwater crabs and shrimps. Memoirs 
of the Queensland Museum, South Brisbane, 33: 17-40.

Cannon, L.R.G. \& K.B. Sewell. 1995. Craspedellinae Baer, 1931 (Platyhelminthes: Temnocephalida) ectosymbionts from the branchial chamber of Australian crayfish (Crustacea: Parastacidae). Memoirs of the Queensland Museum, South Brisbane, 38: 397-418.

Dallwitz, M.J. \& T.A. Paine. 1986. User's guide to the Delta system: a general system for processing taxonomic descriptions. Canberra, CSIRO, Division of Entomology, Report 13, p. 1-106.

Damborenea, M.C. 1994. Temnocefalos neotropicales: Temnocephala kingsleyae sp. n. y T. lutzi Monticelli, 1913 (Platyhelminthes, Temnocephalidea) comensales de crustáceos de Brasil. Iheringia, Série Zoologia, Porto Alegre, 77: 99-105.

Damborenea, M.C. \& L.R.G. Cannon. 2001. On neotropical Temnocephala (Platyhelminthes). Journal of Natural History, London, 35: 1103-1118.

Joffe, B.I.; I.V. SOlOvei \& L.R.G. CANNON. 1995. The structure of the epidermis in Didymorchis (Temnocephalida: Platyhelminthes). Australian Journal of Zoology, Victoria, 43: 631-641.
Magalhães, C. 2003. Famílias Pseudothelphusidae e Trichodactylidae, p. 143-287. In: G.A.S. DE Melo (Ed.). Manual de identificação de Crustacea Decapoda de água doce do Brasil. São Paulo, Editora Loyola, 429p.

Monticelli, F.S. 1913. Brevi communicazioni sulle Temnocefale. Bolletino de Societa Naturalisti, Ser. 3, Napoli, 26: 7-8.

Pereira, C. \& R. Cuocolo. 1941. Estudos sobre "Temnocephalidae Monticelli, 1899", com estabelecimento de dois novos gêneros australianos e descrição de duas novas espécies neotrópicas. Arquivos do Instituto Biológico, São Paulo, 12 (9): 101-127.

Pretzmann, G. 1982. Die westmediterranen Susswasserkrabben. Quaderni del Laboratorio di Tecnologia della Pesca, Ancona, 3 (2-5): 363-366.

RomeIs, B. 1968. Taschenbuch der microskopischen Technik. 16. Munchen, Aufl. Oldenbourg, XIV+695p.

SEwell, K.B. \& L.R.G. Cannon. 1998. New temnocephalans from the branchial chamber of Australian Euastacus and Cherax crayfish hosts. Proceedings of the Linnaean Society, New South Wales, 119: 21-36.

Received in 06.V.2005; accepted in 10.XI.2005. 